\title{
Paradoxes of Modernist Consumption - Reading Fashions
}

\author{
Wilfred Dolfsma
}

\begin{tabular}{|l|l|}
\hline \multicolumn{2}{|l|}{ ERIM REPORT SERIES RESEARCH IN MANAGEMENT } \\
\hline ERIM Report Series reference number & ERS-2004-035-ORG \\
\hline Publication & May 2004 \\
\hline Number of pages & 18 \\
\hline Email address corresponding author & w.dolfsma@fbk.eur.nl \\
\hline Address & Erasmus Research Institute of Management (ERIM) \\
& Rotterdam School of Management / Rotterdam School of Economics \\
& Erasmus Universiteit Rotterdam \\
& P.O.Box 1738 \\
& 3000 DR Rotterdam, The Netherlands \\
& Phone: +31 10 408 1182 \\
& Fax: +31 10 408 9640 \\
& Email: info@erim.eur.nl \\
& Internet: www.erim.eur.nl \\
\hline
\end{tabular}

Bibliographic data and classifications of all the ERIM reports are also available on the ERIM website: www.erim.eur.nl 


\title{
ERASMUS RESEARCH INSTITUTE OF MANAGEMENT
}

\author{
REPORT SERIES \\ RESEARCH IN MANAGEMENT
}

\begin{tabular}{|c|c|c|}
\hline \multicolumn{3}{|c|}{ BIBLIOGRAPHIC DATA AND CLASSIFICATIONS } \\
\hline Abstract & \multicolumn{2}{|c|}{$\begin{array}{l}\text { Fashion is the quintessential post-modernist consumer practice, or so many hold. In this } \\
\text { contribution, I argue that, on the contrary, fashion should be understood as a means of } \\
\text { communicating one's commitment to modernist values. I introduce the framework of the Social } \\
\text { Value Network, to relate such values to institutionalised consumption behaviour, allowing one to } \\
\text { signal to others. Modernist values are not homogenous, and are in important ways } \\
\text { contradictory, giving rise to the dynamics of fashion that can be observed. }\end{array}$} \\
\hline \multirow{3}{*}{$\begin{array}{l}\text { Library of Congress } \\
\text { Classification } \\
\text { (LCC) }\end{array}$} & $5001-6182$ & Business \\
\hline & $5546-5548.6$ & Office Organization and Management \\
\hline & HF 5415.32 & Consumer behaviour \\
\hline \multirow{3}{*}{$\begin{array}{l}\text { Journal of Economic } \\
\text { Literature } \\
\text { (JEL) }\end{array}$} & $\mathrm{M}$ & Business Administration and Business Economics \\
\hline & $\begin{array}{l}\text { M } 10 \\
\mathrm{~L} 2\end{array}$ & $\begin{array}{l}\text { Business Administration: general } \\
\text { Firm Objectives, Organization and Behaviour }\end{array}$ \\
\hline & D 12 & Consumer Economics: Empirical Analysis \\
\hline \multirow{3}{*}{$\begin{array}{l}\text { European Business Schools } \\
\text { Library Group } \\
\text { (EBSLG) }\end{array}$} & $85 \mathrm{~A}$ & Business General \\
\hline & $\begin{array}{l}100 B \\
240 B\end{array}$ & $\begin{array}{l}\text { Organization Theory (general) } \\
\text { Information Systems Management }\end{array}$ \\
\hline & $280 \mathrm{~N}$ & Consumer behaviour \\
\hline \multicolumn{3}{|c|}{ Gemeenschappelijke Onderwerpsontsluiting (GOO) } \\
\hline \multirow[t]{3}{*}{ Classification GOO } & 85.00 & Bedrijfskunde, Organisatiekunde: algemeen \\
\hline & $\begin{array}{l}85.05 \\
85.08\end{array}$ & $\begin{array}{l}\text { Management organisatie: algemeen } \\
\text { Organisatiesociologie, organisatiepsychologie }\end{array}$ \\
\hline & 85.40 & Marketing \\
\hline \multirow[t]{3}{*}{ Keywords GOO } & \multicolumn{2}{|c|}{ Bedrijfskunde / Bedrijfseconomie } \\
\hline & \multicolumn{2}{|c|}{ Organisatieleer, informatietechnologie, prestatiebeoordeling } \\
\hline & \multicolumn{2}{|c|}{ Consumentengedrag, modernisme, mode, symbolisch interactionisme } \\
\hline Free keywords & \multicolumn{2}{|c|}{ Consumption, modernism, fashion, identity, symbolic goods } \\
\hline
\end{tabular}




\title{
Paradoxes of Modernist Consumption - Reading Fashions
}

\author{
Wilfred Dolfsma \\ Erasmus University Rotterdam \& Maastricht University ${ }^{1}$
}

Abstract: $\quad$ Fashion is the quintessential post-modernist consumer practice, or so many hold. In this contribution, I argue that, on the contrary, fashion should be understood as a means of communicating one's commitment to modernist values. I introduce the framework of the Social Value Network, to relate such values to institutionalised consumption behaviour, allowing one to signal to others. Modernist values are not homogenous, and are in important ways contradictory, giving rise to the dynamics of fashion that can be observed.

It is often lamented by academics and others that contemporary patterns of consumption are 'post-modern' (see e.g., Van Raaij 1993). Some perceive of consumption in general as postmodern (Jameson 1988). Its volatility and fickleness is such that it is beyond understanding. In this paper I argue that the characterization of contemporary consumption patterns as post-modern is based on an incorrect understanding of these consumption patterns, as well as an incorrect understanding of the term post-modernity. Underlying present-day consumption patterns are broadly supported socio-cultural values that, the literature on modernism and post-modernism indicates, are thoroughly modernist in nature. Modernist values such as autonomy, novelty, speed, success, and uniqueness underlie consumption patterns. In their consumption, people want

\footnotetext{
${ }^{1}$ Contact: Erasmus University Rotterdam, FBK, PO Box 1738, NL-3000 DR Rotterdam, the Netherlands, w.dolfsma@fbk.eur.nl
} 
to express such values. The volatility and fickleness of consumption patterns is, as I will argue in this short paper, to be explained by reference to the modernist values involved, and by the fact that the modernist values often contradict one another, particularly when expressed in the consumption of concrete objects. The paradoxes that are inherent in modern consumption, particularly as consumption patterns are institutionalized to allow for communication, give rise to the kind of patterns we see today.

Underlying post-modern accounts of consumer culture is the 'loss of the real' (Slater 1997, p.198), and an idea that such culture cannot be understood. Contemporary consumption patterns are, however, not beyond understanding. And they are certainly not post-modern, as the short first section argues. There is a need to incorporate into the analysis explicitly the concept of (socio-cultural) values, and the expression of these in institutions. In Section 2, I elaborate on this point and discuss the Social Value Nexus I have introduced elsewhere (Dolfsma 2004). Section 3 discusses and analyses fashion from the point of view of this perspective, drawing on secondary sources. This believed to be quintessential post-modern consumption practice is best understood from the social and institutional economic framework presented in Section 2. Final remarks follow in Section 4.

\section{Modernism, Post-Modernism and Consumption}

The view expounded by Frankfurter Schule scholars such as Adorno (cf. his 1941) of consumers being mindless creatures that can be manipulated at will into buying goods has long been an influential one. Not only scholars inspired by the work of Marx, on the 'left', but also scholars on the 'right', being more inclined to the rational choice school of though in sociology and the neoclassical school of thought in economics have thus given the phenomenon of consumption short shrift. Despite consumption being the sole end of production, as Adam Smith has said famously, only marketing scholars have given it considerable attention. Residing in business schools, their attention is often not trusted as a genuine scientific contribution. In more recent 
times, consumption and fashion in particular have been called post-modern. Indeed "comtemporary postmodern society is best defined as a "consumer society"” (Firat \& Venkatesh 1993, p.228), and 'hype' (or fashion) the quintessential form of consumption (op.cit., p.230).

Consumption is not the act of purchase, but involves much more, also on the part of the consuming individual (Miller 1995). It is true that an increasingly large number of products are being offered on the market - a larger number than in previous eras. Many products' life and times seem entirely incomprehensible: why do some succeed incredibly and others fail miserably is often difficult to comprehend. The regularity and predictability that science looks for seem to be lost. The task of scientists looking for and explaining patterns in consumption behaviour becomes (much) more, and some even suggest insurmountably difficult (Venkatesh 1999) - to the point of giving up hope, it would seem, of trying to understand the patterns other than as 'post-modern'. In fact, however, post-modernism signifies ambiguity, compelling people to be reflexive and to continuously reassess meanings and positions (Kaiser et al. 1991).

Qualifying present-day consumption as incomprehensible and (thus) post-modern is based on two related misunderstandings. The first misunderstanding is about the terms modernity and post-modernity. Modernity is often regarded as ordered, whereas post-modernism is seen as the opposite: chaos (e.g., Sherry 1991). Modernism and post-modernism are, of course, not to be perceived as historic periods, but as characterizations of society, or better still as characterizations of worldviews (ideologies). Post-modernism is defined in negative terms: it is not ordered but fragmented, hyper-real, it de-centers the subject, and it involves paradoxical juxtapositions (Firat 1993, van Raaij 1993, Firat \& Schultz 1997). The very modernist nature of such an opposition often fails to transpire. Post-modernism, it is claimed, should be understood differently. Secondly, the misunderstanding of post-modernism makes scholars disqualify present-day consumption patterns all to quickly. These patterns purportedly remain unexplained. Now the debate about modernism and post-modernism of course is a contested one and hotly debated. My point here is to argue that whatever the merits or demerits of (post-) modernist 
philosophical perspectives, the phenomenon of present-day consumption of fashionable items is best understood as modernist.

Modernism is, of course, a rationalistic view of the world, where knowledge is relentlessly accumulated and progress inevitable. The world outside is contrasted with the representation that the individual has off it in his own mind. Such a representation, trying to find a central meaning, is necessarily reductionist and formal, often based on axioms only (Klamer 1995, Firat \& Venkatesh 1993). A fundamental, invariant structure that underlies appearance is hypothesized, and so the thinking in terms of universals and unity can be observed. The world is perceived as working towards completion, equilibrium. Machines and mechanistic processes are the preferred metaphors. The world out there is ephemeral, however, and representation is problematic. Some, then, equate reality with the individual's representation of it. However one may think about this issue, it is true that it is the individual who represents the world and not some larger social entity, even when one were to believe, as is the position here, that the former is influenced by the latter (Dolfsma 2004). The natural sciences, specifically before Quantum Mechanics developed, are exemplary (Mirowski 1989). The individual stands at the center in the modernist project (Slater 1997). ${ }^{2}$ The individual makes his own choices - he is sovereign. The idea that the individual might not be fully in control of his action tends anathema in a modernist perspective, but is not necessarily alien to it. Considering individuals, and consumers particularly, as socially connected (Belk 1995) does not entail taking a stance that should be characterized as post-modern, even when accepting the description of post-modern consumption that proponents of it give (Venkatesh 1999).

Modernism is not single-minded, homogenous and without contradictions however (Lefebvre 1995). Different societal and theoretical developments can lead to fragmentation, a fragmentation which is also acknowledged by 'modernist' scholars such as Jürgen Habermas and

\footnotetext{
2 Etymologically, 'Individual' derives from the Latin individuum -indivisible- and further back from the Greek 'atomos' -impossible to cut.
} 
Max Weber. In relation to this, Lichtblau (1999) argues that modernist society has a

'fundamentally dynamic character', consisting of various 'subsystems', that modernity itself is 'internally split' and 'self-differentiating'. What he calls 'the socio-structural core of modernity' is by no means ordered and continuous.

\section{Paradoxical, Modernist Consumption}

There is no sea change in consumption patterns that justifies calling a latter period a post-... era. ${ }^{3}$ Changes in patterns may have sped up and led to fragmentation - but the point made in this paper is that this does not mean a different process is now at work. Present-day consumption patterns are predicated on the very modernist values that they have been predicated on before. The internal paradoxes of these values, I will argue here, is now more pronounced than it was before, causing the dynamics that can be seen. Social influences, manifesting themselves indirectly and not necessarily directly through the observable actions of groups or organizations play an important part in this. Scholars such as Mary Douglas (1986) have pointed to this convincingly.

The modernist ideas or socio-cultural values in society that one should be autonomous, successful, be different from others cause the dynamics of consumption. These socio-cultural values need to be expressed in a way that makes them understandable for others (Cosgel 1997). Hence the observation Simmel (1957, p.546) made with regard to fashion that there is a simultaneous "need of union on the one hand and the need of isolation on the other". 4 The argument that socio-cultural values and the institutionalized way of expressing these are related is depicted in Figure 1. In Dolfsma (2004) the argument is developed further - restrictions of space does not allow extensive discussion here. The relation between values and institutions is not a straightforward one, however. There are two-way relations, although institutions tend to

\footnotetext{
${ }^{3}$ The idea of a sea change is itself a modernist idea, of course. Change, in a modernist conception, is almost inherently good as it is a break with the past and with traditions, creating something new for a beter future.

${ }^{4}$ See also Veblen (1899), but contrast (Campbell 1987).
} 
change faster than socio-cultural values do. Particularly in the case of symbolic goods, which are important in establishing an identity and thus need to signal, enough (relevant) others should understand the signal emanating from consuming something, but not too many for then the message itself is undermined

Figure 1: The Social Value Nexus

Socio-cultural values

Institutional Setting / Institutions

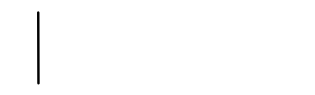

Values

Source: Dolfsma (2004)

Socio-cultural values denote strong underlying convictions many people in a group or in society hold, consciously as well as unconsciously, most of which would be considered of an ethical or philosophical nature. These matters include matters of justice, beauty, love, freedom of will, rightful ways of government and governance, social standing and behavior, and personal identity. When people consume conspicuously they expresses socio-cultural values. ${ }^{5}$ Institutionalized or ritualized (Rook 1999) consumption in large part creates identity, referring to these socio-cultural values. Some goods are, however, more prone to have symbolic meanings than others. Music and dress are among these, but food, art, culture and sports are others. They offer a way of

\footnotetext{
${ }^{5}$ This does not mean that an actual observer will be there to receive the message. Observers may not be present, may be imaginary, or the conspicuous consumption can be directed at the self. The latter is an instance of the well-known phenomenon of self-reward in social psychology, corroborated empirically (Bandura 1986).
} 
communicating messages to the relevant 'audience' (cf. Coşgel 1992, 1994; Douglas \& Isherwood 1979; Crane 2000; Dolfsma 2004), they enable individuals to make and maintain social relations (Douglas and Isherwood 1979, Miller 1995). The socio-cultural values that 'live' in a society or community, and are expressed in its institutional settings, may change over time, but are likely to be persistent. Values, on the other hand, are the terms of trade / exchange established in society for specific goods or services. For this paper, the focus is on the relation between socio-cultural values and institutions. The distinction between socio-cultural values and values is not meant to be exhaustive, but does clarify the discussion considerably. The way in which values are expressed - prices are one example, but there are more ways - differs between different institutional settings where different socio-cultural values are expressed. The distinction between socio-cultural values on the one hand and values on the other is rooted firmly in institutional and social economics as well as in sociology (Beckert 2002, Bush 1987, Davis 2003, Wildavsky 1987). Socio-cultural values do not determine exactly which institutions emerge - indeed, scholars who claim that present-day consumption patterns, and fashion in particular, is post-modern have rightfully pointed to the tenuousness of the relation between observable, institutionalised patterns of behaviour and underlying values. Change can and does go in both directions. Socio-cultural values, however, change much less quickly than institutions do. Changes in the former may take decades or even centuries to materialize (cf. Campbell 1987, Inglehart 1990, Hofstede 1980), even when changes in the latter (usually) are not overnight as well; for one because institutions are interrelated. ${ }^{6}$ The socio-cultural values referred to in a particular domain, such as dress or music, can change, of course; see Dolfsma $(2002,2004)$ for a fuller discussion. Although reference to socio-cultural values in analysing the phenomenon of fashion and its dynamics is rare, some scholars have preceded me in pursuing this route (Ryan

\footnotetext{
${ }^{6}$ Bush $(1987,1106)$ suggests a 'principle of minimal dislocation' suggesting that institutions that are under pressure for change will change such that the effects of the change on the setting as a whole in minimized.
} 
1966, Back 1986). In this light, the frequency with which, for instance, the modernist term 'new' is used hints at this, and it should be surprising that this surprises 'marketers' (Lovelock 1984).

\section{Fashion}

Fashion, but consumption in general, is, because of its associations with emotions, irrationality and improductivity, seldom analyzed in the social sciences. Some consider fashion - clothes and other means of decorating the body - as the quintessential post-modern practice because it is so fickle (Firat \& Venkatesh 1993). ${ }^{7}$ Some point to the production side of the story to explain the dynamics of this practice (Crane 1997, The Economist 2002, 2004). This element is also picked up by economist looking at fashion (Pesendorfer 1995). Although this is undeniably an important aspect, it is not the dominant one.

Fashion is not simply 'high fashion', but may be all clothing etc. used to cover and decorate one's body (Steele 1997). Crane (2000) has argued that in the 1960s there has been a shift from a single fashion -haute couture- to a more fragmented situation where one can distinguish luxury fashion, industrial fashion and street styles. There is a symbiotic relation between high fashion or luxury fashion on the one hand and everyday clothing on the other hand (Steele 1997; Sproles \& Burns 1994), a symbiosis that is reflected in high fashion's dynamics, as Simmel (1957) pointed to. The desire to belong to a certain higher (elite), possibly imaginary group and the simultaneous desire to distinguish oneself from other, lower is manifest in fashion (Thompson \& Haytko 1995, Karni \& Schmeidler 1990). The history of fashion, but also of music, shows a continuously changing scene of styles, emphasizing what I call here different socio-cultural values in a different way (Thompson \& Haytko 1995). An emphasis on functionality, freedom, progress and simplicity in one style of clothing is followed by one on

\footnotetext{
${ }^{7}$ Although fashion is associated by many an observer with femininity (Ireland 1987, Simmel 1957), for the most part because they are believed to expouse the modernist value of rationality to a lesser degree (Bordo 1987). Men, however, have been at least as involved in consuming fashion as women have (Breward 1999, Edwards 1997, Crane 2000).
} 
speed, uniqueness, frivolousness and authenticity (Lewenhaupt \& Lewenhaupt 1989). Besides the mainstreams that exist at any one time in fashion, 'anti-fashions' exist as well (Steele 1997). Some styles present themselves as fashion, others not or as the opposite such as the "AntiFashion" from the 1970s. As Crane (2000, p.167) argues, the sources of fashion have diversified. Ireland (1987) shows how often and to what extent new fashions build on previous ones at the micro level of institutions in design and design process. Even avant-garde designers of fashion use elements from previous fashions when creating a new design, in fact referring to the same values. The institutionalised communication about the new designs, in the media and during fashion parades, refers to such values as well. Thus the signal of fashion consumers is more likely to be understandable, albeit that referring to a modernist socio-cultural value such as novelty and autonomy in an institutionalised manner, they thereby are in danger of signalling about themselves that they are anti-modern, tradionalist. A gratuitous (post-modernist) bric-abrac bringing together of whatever a designer dreams up is available is not what happens (Thompson \& Haytko 1995). ${ }^{8}$ Surely, new fashions appear faster than ever before (The Economist 2004, Crane 2000), and the designs draw on a vaster array of sources, but the ideals and values hankered to have not changed. Fashion is on the cutting edge of presenting novel ideas and imitating from the past, of unicity and demarcation (cf. Simmel 1957, p. 545). Consumption is thus, inevitably, an active and creative undertaking (Thompson \& Haytko 1995, Robins 1994, Dolfsma 2004).

The values that the different styles of fashion hanker after are modernist. Simmel's (1957, p.557) claim that the content of fashion "in abstracto" is irrelevant leaves one in a position where it is impossible to understand the dynamics of consumption patterns and so is unproductive (cf. Dolfsma 2004). One would not consider the socio-cultural values underlying consumption, and their possibly paradoxical nature. One would thus not observe that fashion and

\footnotetext{
${ }^{8}$ This would amount to an Adornian position without the negative connotations about consumers being manipulated into purchasing whatever is on offer (Adorno 1941).
} 
fashion discourses are a continuous juxtaposition of "opposing values and beliefs" (Thompson \& Haytko 1995, p.15), and misunderstand the phenomenon. An adherence to the very same sociocultural values as before has resulted in the 'changed nature of fashion change', becoming 'more complex, erratic' (Crane 2000, p.167). The different dynamics do not indicate a sea change, even when some claim that it does. Elizabeth Wilson in her book Adorned in Dreams - Fashion and Modernity (1985, p.5) has put it thus:

"Changes in fashion styles not only represent reaction against what went before; they may be self-contradictory too."

The paradoxes of modernist consumption - manifest for fashion as well as in pop music- is due to the hankering to the socio-cultural values of authenticity, freedom, novelty, speed, success, autonomy, independence, pleasure, success, youth, and the like, that need to be communicated in a way that is understandable to others (Thompson \& Haytko 1995, p.22; cf. Coşgel 1997). Appearance is therefore a crucial element (Finkelstein 1991, Baudrillard 1981). Within a "interpretative community" a "socially negotiated set of rules of interpretation and aesthetic standards" is needed (Thompson \&Haytko 1995, see also Dolfsma 2004). The rules for interpreting are shared by a community that constructs what might be called a "generalized other, who is consistently characterized as a conformist who is highly sensitive to the opinions of peers" (Thompson \& Haytko 1999, p.22). A real or assumed generalized other is the release valve for pent up tensions due to institutional tensions, or inherently conflicting modernist values (Dolfsma 2002, 2004). Or, as Wilson (1985, p.6) observes “[d]espite its apparent irrationality, fashion cements social solidarity and imposes group norms, while deviations in dress are usually experienced as shocking and disturbing." Thus vulnerability and anxiety are significant factors for consumers (Robins 1994). The dynamics of the phenomenon of fashion - the necessary finiteness of each fashion- is to be understood in those terms (Simmel 1957). Fashions that can 
be observed thus do not constitute or reflect a break with modernism. Indeed they are a clear expression of it (Thompson \& Haytko 1995, Berman 1982). Fashion sometimes referred to as post-modern fashion is, in this respect, no different from the 'New Look' of just after World War II or 'Anti-Fashion' of the 1970s. Different values may be emphasized, but they are all firmly modernist (Enlightenment) values.

Figure 2: Calvin Klein advertisement

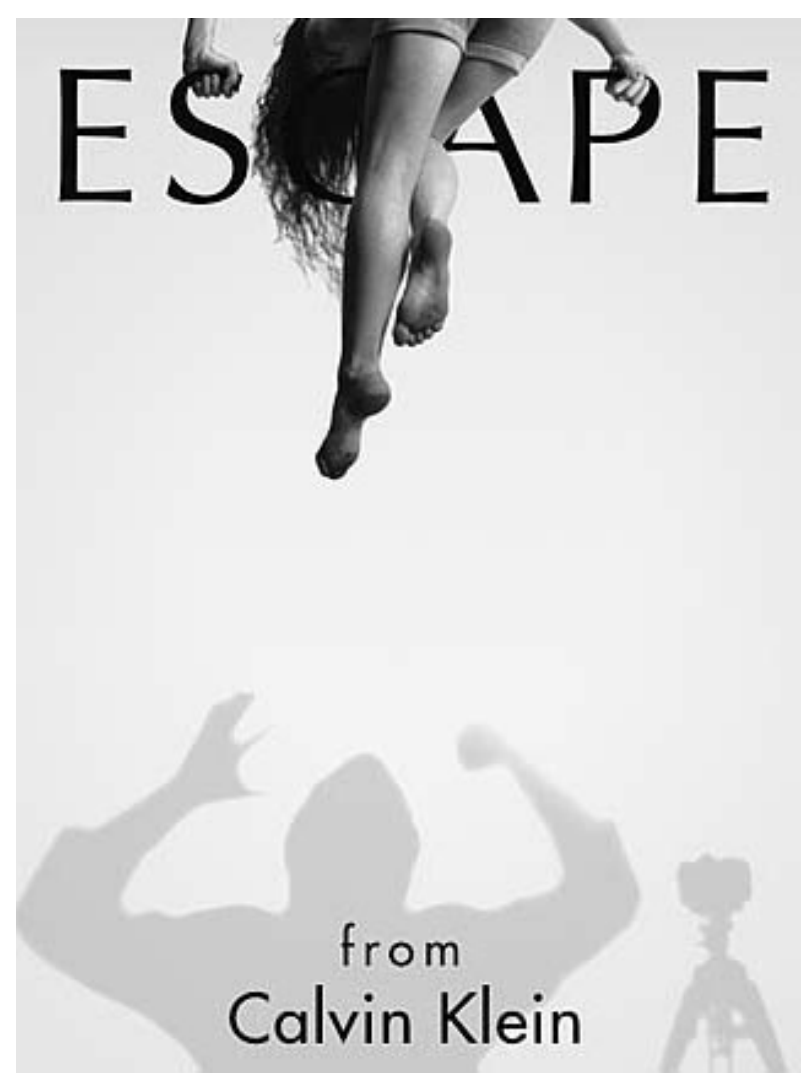

A glance at a random advertisement for a product of fashion, produced and marketed by one of the top firms in the luxury business makes the point (Figure 2). ${ }^{9}$ Other advertisements are similar in the sense that they hanker to modernist values, albeit not necessarily the ones referred to in this ad. Values that are referred to are those of freedom, escaping from (traditions),

\footnotetext{
${ }^{9}$ Actually the choice was not so random, as an advertisement in black \& white was needed as that would be easy to reproduce here.
} 
independence, success and the like. Which values are stressed and to what extent, varies. Of course the way in which such values are expressed (institutionalized) differs too. Of course the advertisements want to persuade the viewer of the specific relation between the values and a type of behavior on the part of the audience.

Buying, using and wearing Calvin Klein apparel is thus a way of signaling certain sociocultural values, even though the products offered by CK might not be the most distinguished and up-market (The Economist 2002). These are modernist values, and consumers express them in routinized or institutionalized ways so the message conveyed can be understood by relevant others. It is, of course, in some part a firm's marketing effort to try to establish the connection between the modernist values and particular products that are involved. Marketing efforts that scholars who stress the post-modernist nature of consumption point to indeed play a role. But this does not obviate the point that, nevertheless, the values involved are modernist, and the message needs to be (broadly) understandable also to people who are not deeply involved in the particular fashion. These two necessities for fashions are paradoxically also the grounds for the demise of each particular fashion. As more people start to pick up on a fashion, the very reason for its existence and attractiveness reneges. The point about fashions is, of course, to distinguish yourself in following it from others, show that you are a autonomous person \&c. The search for a new fashion is then also part and parcel of the phenomenon of fashions. Trying to create a fashion is, then, trying to walk a tightrope - too much novelty will result in a consumption good which sends a message that cannot be understood, while too much commonality means not signaling the proper, modernist values. Fashion, thus, is not the quintessential post-modern kind of consumption, but a thoroughly modernist one making undeniably clear the tensions that modernity is imbued with. 


\section{Consumption and the Good Life}

Friedman (1990, p. 327) argues that consumption especially is the "constituent of selfhood, of social identity"; it defines identity, the nature of power, sickness and well-being. (see also Douglas \& Isherwood 1979). In consuming people signal to others, but consumption is not just an instrumental activity. The idea that consuming is (merely) instrumental is not an unusual position, Campbell (1987) calls it a 'Veblenesque' perspective after Veblen (1899). Frank (1985), Bourdieu (1984) and others take this position. Goods are, however, also consumed for what they represent irrespective of what effects consuming them offer; as Friedman (1994, p. 169) states: "consumption is a material realization, or attempted realization, of the image of the good life." Campbell (1987, p. 89) states it thus:

"Individuals do not so much seek satisfaction from products, as pleasure from the selfillusory experience which they construct from their associated meanings. The essential activity of consumption is thus not the actual selection, purchase or use of products, but the imaginative pleasure-seeking to which the product image lends itself ."

Without acknowledging the form a specific consumption pattern takes, one will be unable to understand the dynamics of consumption patterns (cf. Wilson 1985). There is thus a need to be aware of and analyze the socio-cultural values goods that are consumed are imbued with. I have argued this for pop music elsewhere, showing for that case too that such values are expressed in routines and institutions (Dolfsma 2004, see also Frith 1983, 1987).

In everyday life people recognize that socio-cultural values play a critical role in economic processes, but, with a few exceptions, economists do not recognize this. One of the few schools of thought in economics that takes basic underlying socio-cultural values into account is that of institutional economics (Hodgson 1998). Many have contributed to the theory of institutional change, although not all of these would acknowledge the role socio-cultural values 
play. Rather than developing this part of the argument, I have argued two separate but related thing in this contribution. First, I have argued that a type of consumption which is considered particularly to represent post-modernity (and is thus incomprehensible) is indeed thoroughly modernist. Don Slater's (1997, p.9, italics in original) comment that "consumer culture is bound up with the idea of modernity" must be fully supported. In addition, secondly, I have shown that analysing such a phenomenon by looking at how the socio-cultural values are institutionalised to determine behaviour (summarized in the Social Value Nexus) offers a clear and persuasive theoretical perspective to try to understand even fragmented and fickle consumption phenomena such as that of fashion.

\section{Reference:}

T.W. Adorno (1941) “On popular music” Studies in Philosophy and Social Science 9: 17-48.

K.W. Back (1986) "Modernism and Fashion" in: M.R. Solomon (eds.) The Psychology of Fashion. Lexington, Mass.: Heath, pp. 3-14.

Bandura, A. (1986), Social foundations of thought and action - a social cognitive theory, Englewood Cliffs, NJ, Prentice-Hall.

J. Baudrillard (1981) For a Critique of the Political Economy of Sign. St. Louis, MS: Telos.

J. Beckert (2002) Beyond the Market. Princeton: Princeton UP.

R.W. Belk (1995) 'Studies in the New Consumer Behaviour’ in D. Miller (ed.) Acknowledging Consumption. London \& New York: Routledge, pp. 58-95.

M. Berman (1982) All that is solid melts into thin air. New York: Simon \& Schuster.

Bourdieu, P. (1984) Distinction. A social critique of the judgment of taste. Harvard UP.

S. Bordo (1987) The Flight to Objectivity. State University of New York Press.

C. Breward (1999) The Hidden Consumer - Masculinity, fashion and city life 1860-1914. Manchester \& New York: Manchester University Press. 
P. Bush (1987) “The Theory of Institutional Change," Journal of Economic Issues 21(3): 10751116.

C. Campbell (1987) The Romantic Ethic and the Spirit of Modern Consumerism. Oxford: Basil Blackwell.

M. Cosgel (1997) “Consumption Institutions” Review of Social Economy

D. Crane (2000) Fashion and its Social Agendas. London \& Chicago: The Univesity of Chicago Press.

----, (1997) “Globalization, organizational size, and innovation in the French luxury fashion industry" Poetics 24: 393-414.

J.B. Davis (2003) The Theory of the Individual in Economics - Identity and value. London \& New York: Routledge.

W. Dolfsma (2002) “Mediated Preferences - How institutions affect consumption” Journal of Economic Issues 36(2): 449-457.

----, (2004) Institutional Economics and the Formation of Preferences. Cheltenham: Edward Elgar.

M. Douglas (1986) How Institutions Think. London: Routledge \& Kegan Paul.

The Economist "Luxury goods" March 22, 2002, pp.65-68.

----, "Rags and Riches - a survey of fashion” March 6, 2004.

T. Edwards (1997) Men in the Mirror. London: Cassell.

J. Finkelstein (1991) The Fashionable Self. Cambridge: Polity Press.

Firat, A.F. en C.J. Schultz II (1997) "From Segmentation to Fragmentation: Markets and Market Strategies in the Postmodern Era” European Journal of Marketing 31: 183-207.

A. Firat and A. Venkatesh (1993) "Postmodernity: the age of marketing" International Review of Research in Marketing 10: 227-249.

R. Frank (1985) Chosing the Right Pond. New York \& Oxford: Oxford UP. 
J. Friedman (1990) "Being in the World" Theory, Culture and Society 7: 311-328

----, (1994) “The Political Economy of Elegance,” in J. Friedman, ed., Consumption and Identity. Harwood, pp. 167-87.

G.M. Hodgson (1998) “The Approach of Institutional Economics,” Journal of Economic Literature 36(1).

G. Hofstede (1980) Culture’s Consequences. Sage.

R. Inglehart (1990) Culture Shift in Advanced Industrial Society. Princeton UP.

P.J. Ireland (1987) Encyclopedia of Fashion Details. London: B.T. Batsford.

F. Jameson (1988) "Postmodernism and Consumer Society” in: E.A. Kaplan (ed.) Postmodernism and its Discontents. London: Verso, pp. 13-29.

S.B. Kaiser, R.H. Nagasawa \& S.S. Hutton (1991) "Fashion, Postmodernity and Personal Appearance: A Symbolic Interactionist Formulation." Symbolic Interaction (Summer 1991), 14(2): 165-185.

Karni and D. Schmeidler (1990) "Fixed Preferences and Changing Tastes." American Economic Review 80 (2): 262-7.

A. Klamer (1995) “The conception of modernism in economics” in S. Dow \& J. Hillard (eds.) Keynes,Knowledge and Uncertainty. London: Edward Elgar, 318-333.

K. Lichtblau (1999) “Differentiations of Modernity” Theory, Culture and Society 16(3): 1-30.

H. Lefebre (1995) Introduction to Modernity, London: Verso.

T. Lewenhaupt and C. Lewenhaupt (1989) Crosscurrents - Art, Fashion, Design (1890 - 1989). New York: Rizzoli.

C.H. Lovelock (1984) “Developing and Implementing New Services”, in: W.R. George en C.E. Marshall (ed.) Developing New Services. Chicago, Ill.: American Marketing Association, 
pp. 65-97.

D. Miller (1995) “Consumption as the Vanguard of History” in D. Miller (ed.) Acknowledging Consumption. London \& New York: Routledge, pp.1-57.

P. Mirowski (1989) More heat than light: Economics as social physics, physics as nature's economics. Cambridge: Cambridge UP.

W. Pesendorfer (1995) "Design Innovation and Fashion Cycles” American Economic Review 85: 771-92.

W. F. Van Raaij (1993) “Postmodern consumption” Journal of Economic Psychology 14: 54163.

K. Robins (1994) “Forces of Consumption” Media, Culture \& Society 16: 449-468.

D.W. Rook (1999) "Ritual” in: P.E. Earl \& S. Kemp (eds.) The Elgar Companion to Consumer

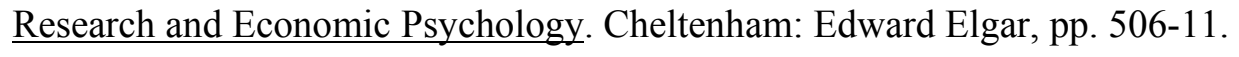

M.S. Ryan (1966) Clothing: A study in human behavior. New York: Holt, Rinehart and Winston. J. Sherry (1991) "Postmodern Alternatives" in: T.S. Robertson \& H. Kassarjian (eds.) Handbook of Consumer Research. Englewood Cliffs, NJ: Prentice Hall, pp. 548-91.

G. Simmel (1957 [1904]) “Fashion”, The American Journal of Sociolgy 62(6): 541-558.

D. Slater (1997) Consumer Culture and Modernity. Cambridge, MA: Polity Press / Blackwell.

G.B. Sproles and L.D. Burns (1994) Changing Appearances - Understanding Dress in Contemporary Society. New York: Fairchild.

V. Steele (1997) Fifty years of fashion. New Haven \& London: Yale U.P.

C. Thompson and D.L. Haytko (1995) “Speaking of Fashion: consumers' uses of fashion discourses and the appropriation of countervailing cultural meanings," Journal of Consumer Research 24(1): 15-42.

T. Veblen (1994 [1899]) The Theory of the Leisure Class. New York: Dover.

A. Venkatesh (1999) "Postmodernism and Consumption" in: P.E. Earl \& S. Kemp (eds.) The 
Elgar Companion to Consumer Research and Economic Psychology. Cheltenham:

Edward Elgar, pp. 458-463.

A. Wildavsky (1987) “Choosing Preferences by Constructing Institutions: A Cultural Theory of Preference Formation," American Political Science Review 81: 3-21.

E. Wilson (1985) Adorned in Dreams - Fashion and Modernity. London: Virago. 


\section{Publications in the ERIM Report Series Research* in Management}

\section{ERIM Research Program: "Organizing for Performance"}

\section{4}

Learning And Governance In Inter-Firm Relations

Bart Nooteboom

ERS-2004-003-ORG

http://hdl.handle.net/1765/1122

Organisational Learning And Multinational Strategy

Bart Nooteboom

ERS-2004-004-ORG

http://hdl.handle.net/1765/1123

Density And Strength Of Ties In Innovation Networks: A Competence And Governance View

Bart Nooteboom and Victor A. Gilsing

ERS-2004-005-ORG

http://hdl.handle.net/1765/1124

Innovation, learning and cluster dynamics

Bart Nooteboom

ERS-2004-006-ORG

http://hdl.handle.net/1765/1125

Empirical Tests Of Optimal Cognitive Distance

Stefan Wuyts, Massimo G. Colombo, Shantanu Dutta, and Bart Nooteboom

ERS-2004-007-ORG

http://hdl.handle.net/1765/1126

Entrepreneurship in Transition: Searching for governance in China's new private sector

Barbara Krug and Hans Hendrischke

ERS-2004-008-ORG

http://hdl.handle.net/1765/1128

Exploring Emotional Competence: Its effects on coping, social capital, and performance of salespeople Willem Verbeke, Frank Belschak and Richard P. Bagozzi

ERS-2004-014-ORG

http://hdl.handle.net/1765/1174

The Impact of Business Ownership Change on Employee Relations: Buy-outs in the UK and the Netherlands Hans Bruining, Paul Boselie, Mike Wright and Nicolas Bacon ERS-2004-021-ORG

http://hdl.handle.net/1765/1263

* A complete overview of the ERIM Report Series Research in Management: https://ep.eur.nl/handle/1765/1

ERIM Research Programs:

LIS Business Processes, Logistics and Information Systems

ORG Organizing for Performance

MKT Marketing

F\&A Finance and Accounting

STR Strategy and Entrepreneurship 
Towards a Dynamic (Schumpeterian) Welfare Economics

Wilfred Dolfsma

ERS-2004-026-ORG

http://hdl.handle.net/1765/1264

The Three-Step Test-Interview (TSTI): An observational instrument for pretesting self-completion questionnaires

Tony Hak, Kees van der Veer and Harrie Jansen

ERS-2004-029-ORG

http://hdl.handle.net/1765/1265

Measuring the Knowledge Base of an Economy in terms of Triple-Helix Relations among 'Technology, Organization, and Territory'

Loet Leydesdorff, Wilfred Dolfsma \& Gerben van der Panne

ERS-2004-034-ORG

http://hdl.handle.net/1765/1300 